\title{
Social Welfare Standards Detailing in Certification of Agri-Food Products
}

\author{
Lara Bartocci Liboni \\ University of São Paulo, Brazil \\ School of Business and Economics \\ E-mail: lara.liboni@gmail.com
}

Julio Kyosen Nakatani

Business Department

University of São Paulo - FEARP, Brazil

E-mail: jknakatani@gmail.com

Luciana Oranges Cezarino

University of Sao Paulo, Brazil

E-mail: 1cezarino@gmail.com

Received: August 16, 2012 Accepted: September 21, 2012 Published: October 1, 2012

doi:10.5296/jmr.v4i4.2233 URL: http://dx.doi.org/10.5296/jmr.v4i4.2233

\begin{abstract}
The objective was to know the detailing level of social standards in third-party Agri-food certifiers. An exploratory qualitative analysis was conducted using secondary data collected from certifiers of Agri-food products. The results showed that most certifications did not address consumers' values regarding social sustainability. Certifiers should deep efforts in describing social welfare standards to communicate with consumers clearly. This would improve the certification image, increase the perceived products value, address consumer demands, and achieve social sustainability in labor relationships along the entire supply chain.
\end{abstract}

Keywords: Certification, Social Sustainability, Agri-food products 


\section{Introduction}

The agri-food sector encompasses all agricultural products destined for human consumption (Ahumada \& Villalobos, 2009). Certification is particularly important for retailers seeking to guarantee a superior-quality product and to charge a premium price (Higgins et al., 2008). New kinds of consumer and supply-chain governance have led to demandls that certifications provide more features and higher-quality information (Mutersbaugh et al., 2005). One feature that is gaining importance is information about social welfare provided by third-party certifiers.

Certifications must meet standards and take into account stakeholders' interests (Hatanaka et al., 2005) in environment, social welfare and economics issues. In reality, not all messages passed from the retailer to the consumers of a certified product can be verified. Another major problem is that the verification of measures of social welfare used in third-party certification is not considered to be a main issue, even for "fair" labels (Getz \& Shreck, 2006). In practice, although these certifications must show some concern for social issues, environmental issues command most attention in assessing the sustainability of products.

The assessment of whether the certifications meet proposed standards (e.g., environmental, economic, and social) for all products and the investigation of economic implications for producers and retailers (Harris, 2007; Ilbery et al., 2005) have been central topics in studies of certification. The documentation and measurement of social welfare in work relationships involved in the production and commercialization processes have been considered problematic issues in the agricultural sector (Higgins et al., 2008).

\section{Objectives}

The present study had two objectives: to identify third-party certifiers' evaluation standards regarding the social welfare of workers in agri-food production and commercialization, and to determine whether these social certifications meet social sustainability standards in agricultural product systems.

\section{Research design}

This study was an exploratory qualitative analysis of secondary data collected from nine third-party certifiers of agri-food products. Malhotra (2006) defined exploratory analysis as that approached with "no preconceived notions of possible answers to the research questions, nor the ability to produce statements of relationships or propositions" (p. 49). Standards concerning labor issues that were available on the certifiers' websites and printed documents about those certifications were analyzed, followed by comparison of these data with those reported in literature available in academic journal databases. Nine third-party certifiers (Table 1) were selected according to the acceptance of their standards in the European market: Certified Fair Labor, Fair Trade, Global G.A.P., Rainforest Alliance, Food Alliance, IBD Certification, International Federation of Organic Agriculture Movements (IFOAM), Protected Harvest, and GreenTick. 
Table 1. Certification and third-party certifiers

\begin{tabular}{|c|c|}
\hline Certificate & Third-party certifier \\
\hline 1 Certified Fair Labor & Scientific Certification Systems ${ }^{\circledR}$ \\
\hline 2 Fair Trade & Fairtrade Labelling Organizations International $^{\circledR}$ \\
\hline 3 Global GAP & GLOBAL G.A.P. North America Inc. ${ }^{\circledR}$ \\
\hline 4 Rainforest Alliance & Rainforest Alliance ${ }^{\circledR}$ \\
\hline 5 Food Alliance & Food Alliance $^{\circledR}$ \\
\hline 6 IBD & IBD Certifcation \\
\hline 7 IFOAM & International Federation of Organic Agriculture Movements \\
\hline 8 Protected Harvest & Protected Harvest \\
\hline 9 GreenTick & GreenTick $^{\circledR}$ \\
\hline
\end{tabular}

\section{Agri-food Certification Overview}

Studies of product sustainability and quality improvement have suggested that social certification could achieve success for agri food companies (Blumenthal \& Haspelagh, 1994; Carr, 1991; Dering, 1998; Grant et al., 1994; Johnson \& Walck, 2004; Jones, 1992; Juscheter et al., 1998). Certification companies aim to assure that their managers are concerned about meeting the requirements for a superior and sustainable product through certification standards (Johnson \& Walck, 2004). However, many authors (Carter, 1999; Dass \& Parker, 1999; Hart et al., 2000; Johnson \& Walck, 2004) have pointed out that the implementation of these standards is complex and expensive. They are designed according to specific criteria, such as integrity, transparency, branding, and a practical definition of sustainability (Harris, 2007).

By definition, certification is a formal method of differentiating products and processes from ones conventionally used in the market (Higgins et al., 2008; Sonnino \& Marsden, 2006). Certified products should meet standards associated with the product and process or place of production. Statements made about these standards are generally audited and verified by a third-party, and then communicated to consumers through labeling (Ilbery et al., 2005). However, the information communicated by companies about the social and natural sustainability of a product does not always reflect actual practice (Bryant \& Goodman, 2004; Getz \& Shreck, 2006). Certification criteria for agri-food products differ within this sector; the standards used in organic farming systems and agricultural fair trade networks employ broadly different criteria to assess the social components of production (Buck et al., 1997; Getz \& Shreck, 2006).

Agri-food producers are among the main users of certification, which is generally requisite for trade in international and global markets (Van Der Grijp et al., 2005). To guarantee the quality and safety of these products, attention to supply chain management, which requires the establishment of codes of conduct, standards for public reporting, and certification programs, is becoming more common (Van Der Grijp et al., 2005). Some authors have defended this kind of certification because it retains some independence from agents with 
interests in managing information about food or agricultural production, and because it increases trust and legitimacy for stakeholders envolved (Hatanaka et al., 2005).

Certification programs can develop closer relationships between producers and consumers by aligning participants' practices and providing information about products attainment of regulatory standards to market (Higgins et al., 2008). However, Mutersbaugh et al. (2005) pointed out that certification serves a more complex role than as a market instrument alone because it is affected by diverse actors' interests. Many authors (Giovannucci \& Ponte, 2005; Hatanaka et al., 2005; Morgan et al., 2006) have noted that certification is becoming a solution to demand for foods that are produced in environmentally, ethically, and socially fair ways. Adherence to social standards involved in certification is expected to benefit workers, families, and communities (Getz \& Shreck, 2006), improving not only the environment and economy, but also the welfare of all stakeholders involved in agri-food production (Giovannucci and Ponte, 2005). Many prerequisites have been proposed for the certification of social sustainability in the agricultural sector, but they have not been analyzed in detail or assessed using the criteria of viability and integrity of certification.

The standards of the third-party certifiers, presented in Table 1 were used to understand the link between social welfare issues in Agri-food production and commercialization. Social sustainability was considered as producers' concern about hiring and employment practices, workplace conditions, access to services for workers and their families, addressing local and regional impacts, providing local and regional community support, and economic viability. All of these factors were considered to be critical for at least adaptation from legal issues.

As it is shown in Figure 1 standards of social welfare issues are investigated in Agri-food production and commercialization.

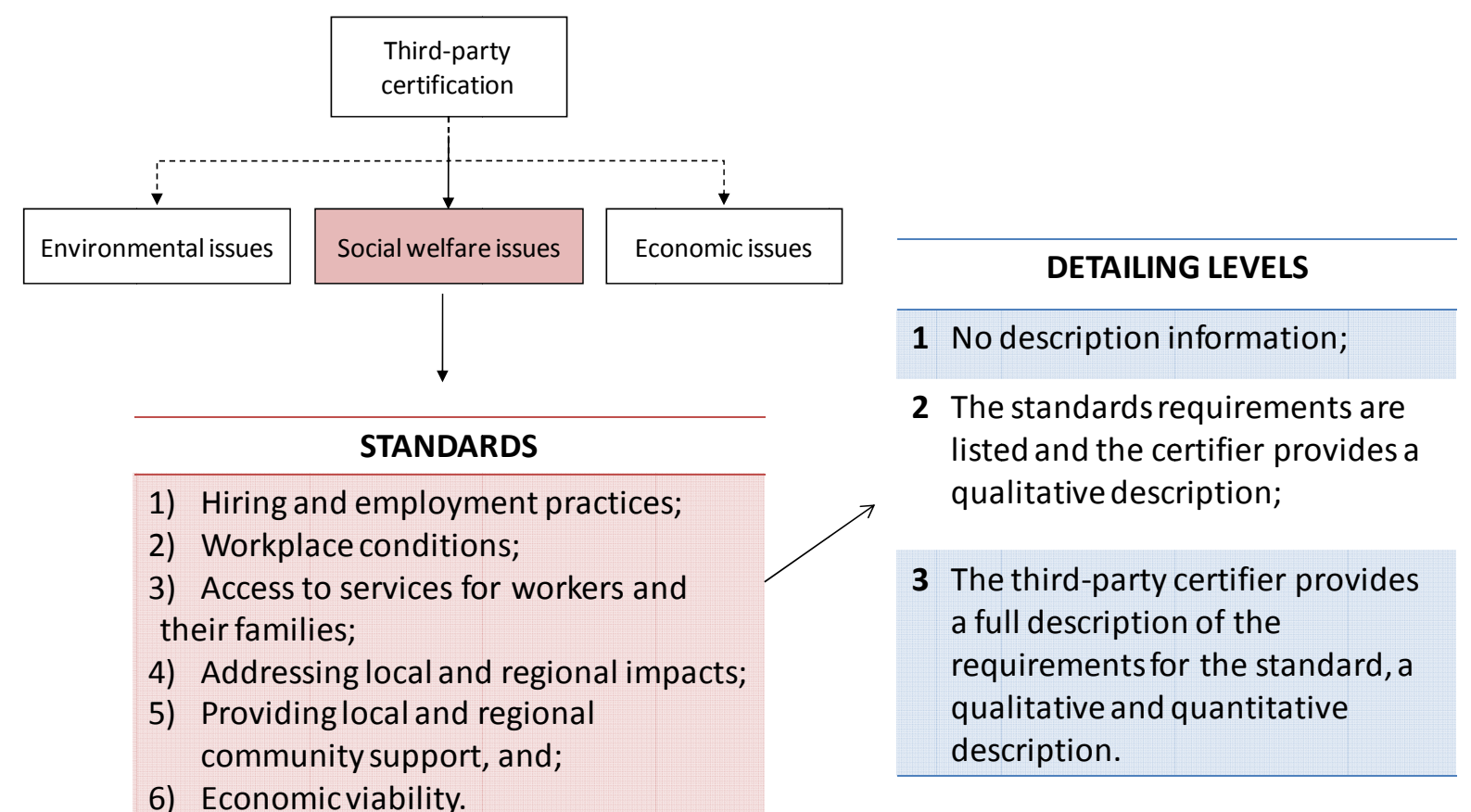

Figure 1. Analytical Framework 


\section{Macrothink}

The first step was to measure the description detailing provided by certifiers for each standard. They were scaled as: 1) the third-party certifier listed only the requirements for the standard, with no other information; 2) the third-party certifier listed the requirements for the standard and provided a qualitative description of the item; and 3) the third-party certifier provided a full description of the requirements for the standard, a qualitative and quantitative description of the item, and information about the data collection method.

\section{Results}

Protected Harvest did not provide a list of such standards on their website or in printed documents. Two certifiers (GreenTick and IFOAM) did not document at least one measurement of social welfare, and were classified within the second level of detail. All other certifiers were classified within the third level of detail, and only Fair Labor had the maximum score for all measurements. The results of analysis are compiled in Table 2.

Table 2. Analysis of information provided by third-party certifiers about social in agri-food production and commercialization.

\begin{tabular}{|c|c|c|c|c|c|c|c|}
\hline rtifier & $\begin{array}{l}\text { Hiring } \\
\text { and } \\
\text { nploym } \\
\text { ent } \\
\text { ractices }\end{array}$ & $\begin{array}{l}\text { rkplace } \\
\text { ditions }\end{array}$ & $\begin{array}{l}\text { :cess to } \\
\text { rices for } \\
\text { kers and } \\
\text { their } \\
\text { milies }\end{array}$ & $\begin{array}{l}\text { Aressing } \\
\text { cal and } \\
\text { :gional } \\
\text { npacts }\end{array}$ & $\begin{array}{l}\text { oviding } \\
\text { cal and } \\
\text { zgional } \\
\text { nmunity } \\
\text { unport }\end{array}$ & $\begin{array}{l}\text { zonomic } \\
\text { 'iability }\end{array}$ & Total \\
\hline Labor & 3 & 3 & 3 & 3 & 3 & 3 & 18 \\
\hline$r$ Trade & - & - & - & 1 & - & 3 & 4 \\
\hline )al GAP & 3 & 1 & 1 & 1 & - & - & 6 \\
\hline $\begin{array}{l}\text { nforest } \\
\text { liance }\end{array}$ & 3 & 3 & 3 & 3 & 3 & 1 & 16 \\
\hline Alliance & 3 & 3 & 3 & - & - & - & 6 \\
\hline IBD & 2 & 2 & 2 & 3 & 2 & 2 & 13 \\
\hline OAM & 1 & 1 & 1 & - & 1 & - & 4 \\
\hline enTick & 1 & 1 & - & - & - & - & 2 \\
\hline $\begin{array}{l}\text { Jtected } \\
\text { arvest }\end{array}$ & - & - & _ & - & - & - & \\
\hline
\end{tabular}

\section{Discussion}

The detailing level of social welfare in third-party certifiers was considered below expectations, in the nine certifiers consulted just three of them presented numbers higher than 
13 points, five of them were in 2-6 points range and one got zero point. Although the score adopted was only for comparison level it was clear that a whole standards description is missing in the most of the Agri-food certifiers. The Agri-food producer and industry will not have clear instructions of what to do in social welfare issues when certification driving management of its business. Standards description also varies trough more detailed as Hyring and Employment Practices to Economic Viability.

Sustainable production is not possible if farmers and industries are not "in tune" with three pillars of sustainability. Therefore Agri-food producers' concern about social welfare is of great importance to non-governmental organizations and consumer activists (Hatanaka et al., 2005). Retailers use the image of a socially sustainable, fair, and superior-quality product (Johnson \& Walck, 2004), but these factors cannot always be assessed through certification.

Third-party certifiers must communicate their efforts to measure the social aspects of production, which are important guides of consumers' product choice. Certifiers could ensure such communication by making the list of items evaluated available through diverse communication channels, including full descriptions of standards and methods of verifying social sustainability. Like this, the trustworthiness of third-party certification and the perceived value of farmers' products could be increased, and the industry could meet consumer demands while maintaining an association with good practices connected to the social sustainability of labor relationships in the supply chain.

\section{Conclusion and managerial implications}

The inclusion of social assessments in the certification criteria for Agri-food products is not unanimously agreed upon. Certifiers usually specialize in standards related to a given issue, and the scope of this specialization should be considered when choosing whether to obtain environmental or social certification for a product. Even among certifications including social issues, not all third-party certifiers employed the same standards of evaluation. Certifiers were most concerned with the assessment of worker safety standards and workplace conditions, but these aspects are not sufficient to guarantee social welfare. Certifications alone cannot address consumers' values regarding sustainability; the quality and quantity of available information, which are generally of concern to those at the front of the supply chain, must also be assessed. When it comes about social welfare standards description the third-party certifiers do not present deep and detailed information.

\section{References}

Ahumada, O., \& Villalobos, J. R. (2009). Application of planning models in the agri-food supply chain: A review. European Journal of Operational Research, 196, 1-20. http://dx.doi.org/10.1016/j.ejor.2008.02.014

Blumenthal, B., \& Haspelagh, P. (1994). Toward a definition of corporate transformations. Sloan Management Review, 35(3), 101-106. 


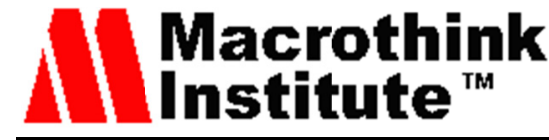

Journal of Management Research

ISSN 1941-899X

2012, Vol. 4, No. 4

Buck, D., Getz, C., \& Guthman, J. (1997). From farm to table: the organic vegetable commodity chain of northern California. Sociologia Ruralis, 37, 3-20. http://dx.doi.org/10.1111/1467-9523.00033

Brasil. (2011). Ministério da Agricultura, Pecuária e Abastecimento. Assessoria de Gestão Estratégica. Projeções do agronegócio. Retrieved from http://www.agricultura.gov.br/ . Access in: 27 november 2011.

Bryant, R. L., \& Goodman, M. K. (2004). Consuming narratives: The Political Ecology of "alternative consumption". Transactions of the Institute of British Geographers, 29, 344-366. http://dx.doi.org/10.1111/j.0020-2754.2004.00333.x

Carter, A. (1999). Integrating quality, environment, health and safety systems with customers and contractors. Greener Management International, 28, 59-68.

Carr, J. T. (1991). Reward right behavior. Journal for Quality and Participation, 68-70.

Dass, P., \& Parker, B. (1999). Strategies for Managing human resource diversity: From resistance to learning. Academy of Management Executive, 13(2), 68-80. http://dx.doi.org/10.5465/AME.1999.1899550

Dering, N. (1998). Leadership in quality organizations. Journal of Quality and Participation, $21,32-35$.

Getz, C., \& Shreck, A. (2006). What organic and fair trade labels do not tell us: toward a place-based understanding of certification. International Journal of Consumer Studies, 30(5), 490-501. http://dx.doi.org/10.1111/j.1470-6431.2006.00533.x

Giovannucci, D., \& Ponte, S. (2005). Standards as a new form of social contract? Sustainability initiatives in the coffee industry. Food Policy, 30, 284-301. http://dx.doi.org/10.1016/j.foodpol.2005.05.007

Grant, R. M., Shani, R., \& Krishnan, R. (1994). TQM's challenge to management theory and practice. Sloan Management Review, 35(2), 25-35.

Harris, S. M. (2007). Does sustainability sell? Market responses to sustainability certification. Management of Environmental Quality, 18, 50-60. http://dx.doi.org/10.1108/14777830710717712

Hart, S., Arnold, M., \& Day, R. (2000). The business of sustainable forestry: Meshing operations whit strategic purpose. Interfaces, 30(3), 234-250. http://dx.doi.org/10.1287/inte.30.3.234.11652

Hatanaka, M., Bain, C., \& Busch, L. (2005). Third-party certification in the global agri-food system. Food Policy, 30(9), 354-369. http://dx.doi.org/10.1016/j.foodpol.2005.05.006

Higgins, V., Dobden, J., \& Cocklin, C. (2008). Building alternative agri-food networks: Certification, embeddedness and agri-environmental governance. Journal of Rural Studies, 24, 15-27. http://dx.doi.org/10.1016/j.jrurstud.2007.06.002 


\section{Macrothink}

Ilbery, B., Morris, C., Buller, H., Maye, D., \& Kneafsey, M. (2005). Product, process and place: an examination of marketing and labeling schemes in Europe and North America. European Urban and Regional Studies, 12(2), 116-132. http://dx.doi.org/10.1177/0969776405048499

Johnson, D., \& Walck, C. (2004). Integrating Sustainability into Corporate Management Systems. Journal of Forestry, 32-39.

Jones, C. (1992). Developing a total quality strategy. Management Services, 36(3), 22-26.

Juscheter, W. M., Fisher, C., \& Alford, R. J. (1998). Five conditions for high- performance cultures. Training and Development, 52(5), 63-67.

Malhotra, N. K. (2006). Marketing research: an applied approach ( $3^{\text {rd }}$ ed.). London: Prentice Hall.

Morgan, K., Marsden, T., \& Murdoch, J. (2006). Worlds of Food: Place, Power and Provenance in the Food Chain. London: Oxford University Press.

Mutersbaugh, T., Klooster, D., Renard, M., \& Taylor, P. (2005). Certifying rural spaces: quality-certified products and rural governance. Journal of Rural Studies, 21, 381-388. http://dx.doi.org/10.1016/j.jrurstud.2005.10.003

Sonnino, R., \& Marsden, T. (2006). Beyond the divide: rethinking relationships between alternative and conventional food networds in Europe. Journal of Economic Geography, 6, 181-199. http://dx.doi.org/10.1093/jeg/lbi006

Van Der Grijp, N. M., Marsden, T., \& Cavalcanti, J. S. B. (2005). European retailers as agents of change toward sustainability: The case of fruit production in Brazil. Environmental Sciences, 2, 31-46. http://dx.doi.org/10.1080/15693430512331333384

Turk A. M. (2009). The benefits associated with ISO 14001 certification for construction firms: Turkish case. Journal of Cleaner Production, 17(5), 559-569. http://dx.doi.org/10.1016/j.jclepro.2008.11.001 